\title{
The Effect of Bacillus subtilis Inoculum Doses and Fermentation Time on Enzyme Activity of Fermented Palm Kernel Cake
}

\author{
Mirnawati $^{1 *}$, G. Ciptaan ${ }^{1}$ and Ferawati ${ }^{1}$ \\ Animal Nutrition Department, Animal Science Faculty, Andalas University, Padang 25163, Indonesia \\ *Corresponding author's Email: mirnawati@ ansci.unand.ac.id; ORCID: 0000-0002-9887-7227
}

Received: 29 Oct. 2019

Accepted: 06 Dec. 2019

\begin{abstract}
Palm kernel cake (PKC) was by-product of palm oil industry and it had potential to be one of the poultry ration ingredient However, its utilization for poultry was still limited because of the $\beta$-mannan in PKC. In order to increase PKC utilization in poultry ration, fermentation process was done to remodeled $\beta$ mannan by using Bacillus subtilis. This research conducted a study on the effect of Bacillus subtilis inoculum dose and fermentation time to increase the enzyme activity of FPKC by using CRD with $3 \times 3$ factorial and 3 replications. Factor A was 3 doses of inoculum Bacillus subtilis: 3\%, 5\%, and 7\%. Factor B was fermentation times which contained: (1) 2 days, (2) 4 days, and (3) 6 days. Parameters used were enzyme activity of mannanase, protease, and cellulase in FPKC. Significant interaction was seen between inoculum doses of Bacillus subtilis and fermentation time. There was also a significant interaction on each of the inoculums dose of Bacillus subtilis and fermentation time on all of the enzyme activity. This study concluded FPKC with Bacillus subtilis of 7\% inoculums doses and 6 days fermentation time indicate the best result as seen from $24.27 \mathrm{U} / \mathrm{ml}$ of mannanase activity, $10.27 \mathrm{U} / \mathrm{ml}$ of protease activity, 17.13 $\mathrm{U} / \mathrm{ml}$ of cellulose activity of fermented PKC.
\end{abstract}

Key words: Bacillus subtilis, Enzyme activity, Fermentation time, Inoculum doses, Palm Kernel Cake

\section{INTRODUCTION}

The availability of feed ingredients is still a common problem experienced by farmers, because of its insufficient availability. Various ways have been tried in order to availability become sufficient. One of the efforts to overcome that problem is by using plantation waste as a cheaper alternative feed ingredient, while not competing with human needs, such as palm kernel cake.

Indonesia as the largest palm oil producer in the world, has produced 45 million tons of palm oil/year (DGP, 2016). In West Sumatra, oil palm plantations have an area of 399,120 hectares, producing 1,145,432 tons palm oil per year (Central Bureau of Statistics, 2015). Each of fresh palm bunches produces $5 \%$ of palm kernel and it also produces $45-46 \%$ of palm kernel cake or $2.0-2.5 \%$ by weight of palm bunches. Nutritional content of palm kernel cake is $17.31 \%$ crude protein, $7.14 \%$ crude fat, $27.62 \%$ crude fiber, $0.27 \% \mathrm{Ca}, 0.94 \% \mathrm{P}$ and $48.4 \mathrm{ppm} \mathrm{Cu}$ (Mirnawati et al., 2018).

The utilization of palm kernel cake in broiler rations is limited to only $10 \%$ (Rizal, 2000). Low utilization of palm kernel cake in poultry rations is due to its high mannan content. As stated by Daud and Jarvis (1993). The $56.4 \%$ of crude fiber content in palm kernel cake is in a form of $\beta$-mannan. However, poultry do not have $\beta$ mannan hydrolysis enzyme in their bodies. In addition to the high crude fiber content in palm kernel cake, its low protein and amino acid digestibility also caused low utilization of palm kernel cake. As well as, Tafsin (2007) found that the low utilization of palm kernel meal in poultry rations is caused by the high content of crude fiber, low digestibility of proteins and amino acids. Fermentation is one of the methods to improve the quality of the palm kernel cake.

Fermentation is a change in chemical material of feed ingredients because of the enzymes produced by microorganisms or existed in these feed ingredients (Buckleet al., 1987; Rizal et al., 2013). Fermented palm kernel cake was done with the help of mannanolytic fungis, for it can produce mannanase enzyme that hydrolyzes mannan. Mirnawati et al. (2017) studied palm kernel cake fermentation using mannanolytic fungis such as Sclerotium rolfsii, Eupenicillium javanicum and Aspergillus niger. The Sclerotium rolfsii has a higher ability among the three fungis to produce enzyme 
compared to Eupenicillium javanicum and Aspergillus niger. Sclerotium rolfsii has mannanase enzyme activity of $24.58 \mathrm{U} / \mathrm{ml}$ and cellulose activity of $21.89 \mathrm{U} / \mathrm{ml}$ and can improve the nutritional quality of palm kernel cake, as seen from $23.66 \%$ of crude protein, $16.72 \%$ of Crude fiber, $0.22 \%$ of crude lipid, $0.75 \%$ of Calcium, $0.85 \%$ of Phosphor, $57.16 \%$ of nitrogen retention, and $25511 \mathrm{kcal} / \mathrm{kg}$ metabolizable energy of palm kernel cake. Although there has been an increase in the nutritional content of fermented palm kernel cake with Sclerotium rolfsii, its utilization in broiler rations is only up to 25\% (Mirnawati et al., 2018).

Fermentation with the help of fungi takes longer time than microbes. According to Fardiaz (1992), microbes as an inoculum requires less time than fungi in the fermentation process, which is about 1-2 days, because the division time is faster. In addition, there are also mannanolytic microbes which are Bacillus subtilis WY34 (Jiang et al., 2006). Hooge (2003) added that Bacillus subtilis can produce several enzymes such as protease, $\beta$ mannanase and several enzymes that are useful in helping digestion so that it is easier to digest. Bacillus subtilis is known to be capable of producing cellulase when placed in an environment containing cellulose. Bacillus subtilis can produce protease, $\alpha$-amylase, and renin (Darwis and Sukara, 1990). Many factors including dose of inoculum and length of fermentation need to be considered following the fermentation process. The application of the right inoculums dose will provide opportunities for rapid growth and development of microbes when more doses of inoculum used, the fermentation process occurs faster, thus more substrates changed. Furthermore, the longer fermentation period lasts, the more substances that are remodeled (Fardiaz, 1992 and Mirnawati et al., 2013).

Therefore, it is necessary to know the optimal dose and duration of palm kernel cake fermentation with Sclerotium rolfsii to produce maximum enzyme activity to increase the nutritional value of palm kernel cake.

\section{MATERIALS AND METHODS}

The materials used in the study were: palm kernel cake, fine bran, Bacillus subtilis InaCC B289, media (NA/ Nutrient Agar), distilled water, buffer solution, and chemicals for analysis of mannanase activity, cellulase and protease. The tools were autoclaved and analytical scales were made in Japan. Incubators, spectrophotometers, and shakers waterbath are made in Jerman. Centrifuges, erlenmeyer, $\mathrm{pH}$ meters were made in China.

This research was conducted using experimental methods using a completely randomized design (CRD), a factorial pattern consisting of 2 treatment factors, namely factors A and B with three replications (Steel and Torrie, 1991). Factor $\mathrm{A}$ is the dose of inoculum, namely: A1 = $3 \%, \mathrm{~A} 2=5 \%$ and $\mathrm{A} 3=7 \%$. Factor $\mathrm{B}$ is the duration of fermentation, namely: $\mathrm{B} 1=$ two days, $\mathrm{B} 2=$ four days and B3 = six days. Measured variables were the activity of Mannanase, cellulase and Protease.

\section{Fermentation}

Fermentation carried out with a ratio of 80.20 palm kernel meal and bran with $60 \%$ moisture content. Materials autoclaved for 15 minutes at $121^{\circ} \mathrm{C}$, Chilled at room temperature then Bacillus subtilis inoculated on ingredients. After inoculation, Bacillus subtilis then fermented in the incubator.

\section{Enzyme extract}

$10 \mathrm{~g}$ of the fermented sample, then soak with $90 \mathrm{ml}$ of $0.05 \mathrm{M} \mathrm{pH}$ buffer phosphate. Leave it in the shaker incubator at $100 \mathrm{rpm}$ for 30 minutes. After that, strain with filter paper and take the filtrate. The filtrate obtained was centrifuged with $10,000 \mathrm{rpm}$, temperature of $-4^{\circ} \mathrm{C}$ for 15 minutes. Take the supernatant and the enzyme activity will be analyzed.

\section{Enzyme activity measurement}

- Mannanase and protease by N-Somogyi Nelson Method Mannanase and protease by N-Somogyi Nelson Method

One $\mathrm{ml}$ of crude enzyme substrate was added to one $\mathrm{ml}$ of manan substrate $(0.5 \mathrm{~g} / \mathrm{ml}$ manan plus $10 \mathrm{ml}$ of phosphate buffer). Incubate for 30 minutes at temperature (40 cellulases and 60 mannanases) in the waterbath shaker. Take one $\mathrm{ml}$ extract of the enzyme that has been incubated, and then add the Nelson AB solution. Heat in boiling water for 20 minutes, after that cool and add one $\mathrm{ml}$ of phosphomolibdat solution and seven $\mathrm{ml}$ of distilled water measure with a Uv-Vis spectrophotometer wavelength $575 \mathrm{~nm}$.

\section{- Protease Protease}

The crude extract of the extracted enzyme determined by its proteolytic activity based on Cupp and Enyard (2008). One ml of crude enzyme extract was added to the casein substrate $0.65 \%(0.65 \mathrm{~g}$ casein in $100 \mathrm{ml}$ Pospat buffer $0.05 \mathrm{M} \mathrm{pH} 7.5$ ). The reaction mixture was incubated at $37^{\circ} \mathrm{C}$ for 10 minutes. Termination of the reaction was carried out by adding five $\mathrm{ml}$ of $110 \mathrm{ml}$ TCA reagent, and re-incubating at $37^{\circ} \mathrm{C}$ for 30 minutes. Two $\mathrm{ml}$ of filtrate was separated by centrifugation at $10000 \mathrm{rpm}$ for 10 minutes. Five $\mathrm{ml}$ of $\mathrm{Na} 2 \mathrm{CO} 3$ and one $\mathrm{ml}$ of Folin 
Ciocalteau reagent were added to the filtrate and incubated at $37^{\circ} \mathrm{C}$ for 30 minutes. The absorbance of the mixture was measured using a UV-vis spectrophotometer at a wavelength of $660 \mathrm{~nm}$.

\section{Data analysis}

Datas obtained were processed statistically by analysis of variance of a completely $b$ randomized design (CRD) with factorial patterns $3 \times 3$ with tree replicates. Differences between treatments test by using Duncan multiple range test (DMRT) (Steel and Torrie, 1995).

\section{RESULTS AND DISCUSSION}

\section{Treatment effect on mannanase activity}

The mean mannanase activity of fermented PKC with Bacillus subtilis was illustrated in table 1. Table 1 showed that there was a tendency of increase in mannanase activity along with the addition of the inoculum dose. Increasing doses of inoculum caused the higher the activity of mannanase on 2 days, 4 days and 6 days of fermentation time. Furthermore, the longer fermentation time increases mannanase activity, at the inoculum dose of $3 \%, 5 \%$ and $7 \%$. The above data could be concluded that the $7 \%$ inoculum and 6-days fermentation time (A3B3) provided the highest mannanase activity.
The high mannanase activity of A3B3 $(6.27 \mathrm{U} / \mathrm{ml})$ was concluded by high doses of inoculum and the longer time of fermentation given to microorganisms allows it to grow and develop rapidly, thus increased mannanase activity. Consistent with Mirnawati et al. (2017) that reported giving the more doses of inoculum caused faster fermentation process, because of the high doses of inoculum that enables increase of enzyme activity and microbial growth in the substrate. Fardiaz (1992) found that the slow pace of fermentation greatly determined the amount of enzymes produced in the media. The longer the fermentation time occurs, the more substrate will be degraded by enzymes produced by microbes. The low mannanase activity in the A1B1 treatment $(15.49 \mathrm{U} / \mathrm{ml})$ was caused by smaller dose of inoculum, which is at $3 \%$ and short duration of fermentation ( 2 days). This caused the slow growth of microbes and low activity of enzyme, however with an increase in the inoculum dose of $7 \%$, the growth of microbes will be better. So, the dose of $7 \%$ inoculum is the optimum doses for the growth of Bacillus subtilis. In accordance with Darwis et al. (1995) at the beginning of fermentation, enzyme activity was very low and it will increase along with the increasing fermentation time. The enzyme activity follows the growth pattern, starts from the phase of adaptation, exponential, stationary and death phase.

Table 1. Mean mannanase activity fermented palm kernel cake with Bacillus subtilis

\begin{tabular}{lcccc}
\hline \multirow{2}{*}{$\begin{array}{l}\text { Factor A } \\
\text { Inoculum Dose) }\end{array}$} & \multicolumn{3}{c}{ Factor B (Fermentation time) } & Mean \\
\cline { 2 - 4 } & B1 (2 days) & B2 (4 days) & B3 (6 days) & $5.52^{\mathrm{aC}}$ \\
A1 & $5.49^{\mathrm{aAB}}$ & $5.62^{\mathrm{aB}}$ & $5.94^{\mathrm{aB}}$ & 5.55 \\
$\mathrm{~A} 2$ & $5.60^{\mathrm{bB}}$ & $5.66^{\mathrm{bAB}}$ & $5.27^{\mathrm{aA}}$ & 5.93 \\
A3 & $5.80^{\mathrm{bA}}$ & $5.81^{\mathrm{bA}}$ & 5.91 & -- \\
Mean & 5.63 & 5.70 & 5.96 \\
\hline
\end{tabular}

Note: Different uppercase letters in different columns and small letters on the same row showed very significant different $(\mathrm{P}<0.05)$. Mean mananase activity is in $\mathrm{U} / \mathrm{ml}$.

\section{Treatment effect on cellulase activity}

The mean cellulase activity of fermented PKC with Bacillus subtilis is shown in table 2. There was an increase of cellulase activity as seen from table 2, along with the addition of the inoculum doses. Cellulase activity was increased at fermentation times ( 2 days, 4 days, and 6 days), proofing that more length of fermentation will increase cellulase activity. Inoculum doses influenced by cellulase activity, evidenced by an increased in cellulase activity with more inoculum doses of $3 \% 5 \%$ and $7 \%$ inoculum doses. From the above data, it can be concluded that the 7\% inoculum dose and 6 days fermentation time (A3B3) provides the highest cellulose activity at 16.11 $\mathrm{U} / \mathrm{ml}$.
The high cellulose activity of A3B3 treatment at $16.11 \mathrm{U} / \mathrm{ml}$ caused by the increasing doses of inoculum and the length of fermentation given which allows the rapid growth and development of microorganisms, so the cellulose activity will be increased. In accordance with the opinion of Mirnawati et al. (2013) that higher dose of inoculum provided better environment for microbial growth causing faster fermentation process while also increasing the enzyme In addition, fermentation time is also one of the determinant factor, where longer fermentation time will cause more remodeled substrate that produced by enzyme of microbes (Mirnawati et al. 2012). 
The low cellulose activity in the A1B2 treatment (5.49 $\mathrm{U} / \mathrm{ml}$ ) caused by low doses of inoculum at $3 \%$ and 4 days of fermentation time. At this treatment, microbes tend to growth slowly and the enzyme activity will be lower. However, the increase in the inoculum dose of $7 \%$ was causing microbes to grow better, thus $7 \%$ inoculum dose is recommended as the optimal dose for the growth of Bacillus subtilis which is in accordance with Zulfatus et al. (2008) that enzyme activity was obtained at post exponential (stationary) time after the 4th day of fermentation. At the incubation period, it was shown that the cellulose enzyme worked optimally in hydrolyzing the substrate, namely cellulose found in palm kernel cake, into glucose.

\section{Treatment effect on protease activity}

The mean protease activity of fermented PKC with Bacillus subtilis is shown in table 3. There is a tendency of an increase in protease activity as presented in table 3, along with the supplementation of inoculum dose. The increased doses of inoculum come with the increased protease activity, both at fermentation times (2 days, 4 days and 6 days). Longer time of fermentation also increases the protease activity, at the inoculum dose of $3 \%, 5 \%$ and $7 \%$.It can be concluded from the above data that the $7 \%$ inoculum dose and 6 days of fermentation time (A3B3) shows the highest protease activity at 10.27 $\mathrm{U} / \mathrm{ml}$. The highest protease activity is shown from A3B3 treatment, it was caused by the increased dose of inoculum and the longer fermentation time, so microorganisms may grow and develop more while also increasing protease activity. In accordance with the opinion of Musaalbakri et al. (2005), the number of inoculums has effect on increasing cell concentration gradually because it increases microbial growth. Thus by increasing the inoculum, the microbes will produce more protease enzymes. Dada et al. (2009) also found that high doses of inoculum added would increase the metabolic compounds produced, while higher inoculum concentrations were also inefficient when the fermentation process was carried out. The longer the fermentation time, the higher the enzyme activity produced. According to Dwidjoseputro (2010) that there is an incubation time in producing metabolic compounds of each bacterium according to the growth phase of each bacterium.

The low protease activity in the A1B3 treatment at $5.36 \mathrm{U} / \mathrm{ml}$ was caused by a small inoculum dose at $3 \%$, resulting in low microbial growth and enzyme activity. The increasing dose of inoculums will provide a better environment for the growth of microbes, thus $7 \%$ inoculum is the optimum dose for the growth of Bacillus subtilis. This is in accordance with the statement of Belma et al. (2000) that reported incubation time affects the cell growth process which occurs through cell division. That process will increase the living cells and the rate of growth in its culture. During the incubation period, it was shown that protease enzymes performed optimally in hydrolyzing the substrate, namely the protein found in palm kernel cake into amino acids and protein quality increases (Mirnawati et al., 2019).

Table 2. Mean cellulase activity of fermented palm kernel cake with Bacillus subtilis.

\begin{tabular}{lcccc}
\hline \multirow{2}{*}{$\begin{array}{l}\text { Factor A } \\
\text { Inoculum Dose) }\end{array}$} & \multicolumn{3}{c}{ Factor B (Fermentation time) } & \multirow{2}{*}{ Mean } \\
\cline { 2 - 4 } A1 & B1 $(\mathbf{2}$ days) & B2 (4 days) & B3 (6 days) & 12.608 \\
A2 & $12.34^{\mathrm{bB}}$ & $12.33^{\mathrm{bC}}$ & $13.15^{\mathrm{aC}}$ & 13.596 \\
A3 & $12.44^{\mathrm{cB}}$ & $13.37^{\mathrm{bB}}$ & $14.97^{\mathrm{aB}}$ & 14.654 \\
Mean & $13.38^{\mathrm{cA}}$ & $14.47^{\mathrm{bA}}$ & $16.11^{\mathrm{aA}}$ & -- \\
\hline
\end{tabular}

Note: Different uppercase letters in different columns and small letters on the same row show very significant different .(P<0.05). Mean cellulose activity is in $\mathrm{U} / \mathrm{ml}$

Table 3. Mean protease activity (U/ml) of fermented palm kernel cake with Bacillus subtilis.

\begin{tabular}{lcccc}
\hline $\begin{array}{l}\text { Factor A } \\
\text { (Inoculum Dose) }\end{array}$ & \multicolumn{3}{c}{ Factor B (Fermentation time) } & \multirow{2}{*}{ Mean } \\
\cline { 2 - 4 } A1 (3\%) & B1 (2 days) & B2 (4 days) & B3 (6 days) & 6.38 \\
A2 (5\%) & $5.85^{\mathrm{aB}}$ & $6.34^{\mathrm{aB}}$ & $5.36^{\mathrm{aC}}$ & 7.31 \\
A3 (7\%) & $6.95^{\mathrm{bA}}$ & $6.68^{\mathrm{abB}}$ & $8.31^{\mathrm{aB}}$ & 8.36 \\
Mean & $7.21^{\mathrm{bAB}}$ & $7.61^{\mathrm{bA}}$ & $10.27^{\mathrm{aA}}$ & \\
\hline
\end{tabular}


Note: Different uppercase letters in different columns and small letters on the same row show very significant different $(\mathrm{P}<0.05)$. Mean Protease activity is in $\mathrm{U} / \mathrm{ml}$.

\section{CONCLUSION}

The high inoculum doses and the longer fermentation time can increase enzyme activity in fermented palm karnel cake. The 7\% inoculum doses and 6-days fermentation time provided optimum results as indicated in mannanase activity $(6.27 \mathrm{U} / \mathrm{ml})$, cellulose activity $(16.11 \mathrm{U} / \mathrm{ml})$ and protease activity $(10.27 \mathrm{U} / \mathrm{ml})$.

\section{DECLARATIONS}

\section{Acknowledgements}

This study was financially supported by funds provided by BOPTN of Andalas University, number 42/UN.16.17/PP.RGB/LPPM/2018, dated April, 23rd 2018.

Author's contribution Mirnawati conducted the research, and prepared data. Gita Ciptaan did the field research and Ferawati performed statistical analysis. All authors checked and confirmed the final form of article

\section{Competing interests}

The authors have declared that no competing interest exists.

\section{Consent to publish}

All authors gave their informed consentprior to their inclusion in the study.

\section{REFERENCES}

Belma A, Zehra N and Yavuz B (2000). Determination of PHB Growth Quantities of Certain Bacillus Species Isolated From Soil. Journal of Biotechnology, Special Issue, pp. 2430. Available

at: http://www.biyotekder.hacettepe.edu.tr/dergi.html

Buckle KA, Edwards RA, Fleet GH and Wooton M (1987). Ilmu Pangan. UI Press, Jakarta.

Central Bureau of Statistic (2015). West Sumatra in numbers. Central Bureau of Statistics, Padang.

Cupp C and Enyard (2008). Sigma's non-specific protease activity assay - casein as a substrate. Journal of Visualized Experiments. 19:899. DOI: http://10.3791/899.

Dada O, Kalil MS and Yusoff WMW (2012). Effect of Inoculum and substrate concertration in anaerobic fermentations of treated rice bran to aceton, butanol and ethanol. $\begin{array}{llll}\text { Bacteriology } & \text { journal } & \text { 79-89. }\end{array}$ DOI: http://10.3923/bj.2012.79.89
Darwis AA, Sailah I, Irawadi T T and Safriani (1995). Kajian Kondisi Fermentasi pada Produksi Selulase dari Limbah Kelapa Sawit (Tandan Kosong dan Sabut) oleh Neurospora sitophila. Jurnal Teknologi Industri Pertanian5 (3) 199$207 . \quad$ Available at: https://repository.ipb.ac.id/jspui/bitstream/123456789/305 59/1/F95SAF.pdf.

Daud MJ and Jarvis MC (1993). Mannan of oil palm kernel. Phytochemistry, 31: 463- 464. DOI: https://doi.org/10.1016/0031-9422(92)90017-K

Darwis AA and Sukara E (1990). Teknologi mikrobial. Departemen Pendidikan dan Kebudayaan. Direktorat Jendral Pendidikan Tinggi. Pusat Antar Universitas Bioteknologi, Institut Pertanian Bogor, pp. 100-165.

Directorate General of Plantations (DGP) (2016). Indonesian Plantation Statistics Department of Agriculture, Jakarta Available at: http://ditjenbun.pertanian.go.id/

Dwidjoseputro D (2010). Dasar-dasar Mikrobiologi, Edisi 14, Djambatan, Jakarta.

Fardiaz S (1992). Teknologi Fermentasi. Jurusan Teknologi Pangan dan Gizi, Fakultas Pertanian, IPB, Bogor.

Hooge D (2003). Bacillus spores may enhance broiler perform. Feed stuffs, 75: 1-5. Available at: https://www.calsporin.com/english01/info/img/index/feeds tuffs.pdf

Jiang Z, WeiY, Li D, L Li, Chai P and Kusakabe I (2006). HighLevel Production, Purification, and Characterization of A Thermostable-mannanase from the Newly Isolated Bacillus subtilis WY34. Carbohydrate Polymers, 66:88-96. DOI: http://10.1016/j.carbpol.2006.02.030.

Mirnawati, Rizal Y, Marlida Y and Kompiang IP (2010). The role of humic acid in palm kernel cake fermented by Aspergillus niger for poultry ration. Pakistan Journal of $\begin{array}{llll}\text { Nutrion, } & 9 & \text { (2): }\end{array}$ DOI: http://10.3923/pjn.2010.182.185

Mirnawati, Kompiang IP and SA Latif (2012). Effect of substrat composition and inoculums dosage to improve quality of palm kernel cake fermented by Aspergillus niger. Pakistan Journal of Nutrition, 11(5): 434-438. DOI: http://10.3923/pjn. 2012. 434.438.

Mirnawati, Djulardi A and Marlida Y (2013). Improving the quality of palm kernel cake fermented by Eupenicillium javanicum as poultry ration. Pakistan Journal of Nutrion, $12 \quad$ (12): 1085-1088. http://10.3923/pjn.2013.1085.1088.

Mirnawati, Djulardi A and Ciptaan G (2018). Utilization of fermented palm kernel cake with Sclerotium rolfsii in broiler ration. International Journal of Poultry Science. 17(7): 342-347. DOI: http://10.3923/ijps.2018.342.347

Mirnawati, Ciptaan G and Ferawati (2017). The effect of Mananolytic fungi and humic acid dosage to improve the nutrient content and quality of fermented palm kernel cake. International journal of Chem Tech Research, 10(2): 56- 
61.

Available

http://www.sphinxsai.com/2017/ch_vol10_no2/1/(56-

61)V10N2CT.pdf

Mirnawati, Ciptaan G and Ferawati (2019). Improving the quality and nutrient content of palm kernel cake through fermentation with Bacillus subtilis. International Journal of Animal and Veterinary Sciences, 31(7). Available at: http://www.lrrd.org/lrrd31/7/mirna31098.html

Musaalbakri AM, Ariff A, Rosfarizan $M$ and Ismail AKM (2005). Kinetics and modeling of red pigment fermentation by Monascus purpures FTC5391 in 2 liter stirred tank fermenter using glucose as a carbon source. Journal Tropical Agriculture and Food Science, 33: 277284. Available

http://psasir.upm.edu.my/id/eprint/48938/

Rizal Y (2000). The respon of broilers to the substitution part of soybean meal for palm kernel cake in the diet. Jurnal Peternakan dan Lingkungan, 2: 15-20.

at:

(1)

Rizal Y, Nuraini, Mirnawati and Mahata ME (2013). Comparisons of nutrients contents and nutritional values of palm kernel cake fermented by using different fungi. Pakistan Journal of Nutrition, 12 (10): 943-948. DOI: https://10.3923/pjn.2013.943.948.

Steel RGD and Torrie JH (1991). Prinsip dan Prosedur Statistik suatu Pendekatan Biometrik. PT. Gramedia Pustaka Utama, Jakarta.

Tafsin M (2007). Polisakarida mengandung manan dari bungkil inti sawit sebagai anti mikroba salmonella trypimurium pada ayam. Media Peternakan, 30: 139-146. Available at: https://journal.ipb.ac.id/index.php/mediapeternakan/article/ view/1003.

Zulfatus S, Ika ISN and Abdullah (2008). Produksi Enzim Selulase oleh Aspergillus niger Menggunakan Substrat Jerami dengan Sistem Fermentasi Padat. (Online), Available at: http://eprints.undip.ac.id/13063/1/ARTIKEL_ILMIAH.pdf 